\title{
Serum calcium dynamics within the first 3 days in milk and the associated risk of acute puerperal metritis
}

\author{
P. L. Venjakob, ${ }^{1}$ R. Staufenbiel, ${ }^{2}$ W. Heuwieser, ${ }^{1 *}{ }^{*}$ and S. Borchardt ${ }^{1}$ \\ ${ }^{1}$ Clinic for Animal Reproduction, Faculty of Veterinary Medicine, Freie Universität Berlin, Koenigsweg 65, 14163 Berlin, Germany \\ ${ }^{2}$ Ruminant Clinic, Faculty of Veterinary Medicine, Freie Universität Berlin, Koenigsweg 65, 14163 Berlin, Germany
}

\section{ABSTRACT}

The objectives of this study were to evaluate postpartum serum calcium dynamics for different parity groups of dairy cows and to assess whether serum calcium concentration on d 0,1 , and 3 postpartum was associated with the risk of developing acute puerperal metritis (APM). The study took place on a commercial dairy farm in northern Germany and included 4,043 Holstein dairy cows. Calving difficulties, such as dystocia, twins, or stillbirth, were recorded. Blood samples were obtained on d 0,1 , and 3 after calving for analysis of serum calcium concentration. Animals were examined daily for clinical symptoms of retained placenta, APM, mastitis, and displaced abomasum until $10 \mathrm{~d}$ in milk. To determine serum calcium dynamics postpartum, we performed repeated-measures ANOVA with first-order autoregressive covariance. A logistic regression model was used to evaluate the association of serum calcium concentration with the risk of developing metritis. Serum calcium concentration was affected by time relative to calving, parity, and APM. Increasing parity negatively affected serum calcium concentration on d 0 and 1 . Serum calcium concentration reached its lowest level on d 1 and 3 in multiparous and primiparous cows, respectively. The concentration increased from $\mathrm{d} 1$ to 3 in multiparous cows and decreased from d 0 to 3 in primiparous cows. The association of APM and serum calcium dynamics varied by parity. On d 3, serum calcium concentration was significantly lower in animals with subsequent APM than in those without APM. The overall incidence of APM was $12.0 \%$ (primiparous cows, $20.4 \%$; multiparous cows, $8.6 \%$ ). An association existed between serum calcium concentration on d 3 after calving and APM. Primiparous cows had an odds ratio of 0.12 for serum calcium concentration on $\mathrm{d} 3$,

Received April 1, 2019.

Accepted July 18, 2019

*Corresponding author: w.heuwieser@fu-berlin.de indicating that a primiparous cow with serum calcium concentration of $2.5 \mathrm{mmol} / \mathrm{L}$ had a $88 \%$ lower chance of developing APM compared with a cow with a concentration of $1.5 \mathrm{mmol} / \mathrm{L}$. Multiparous cows had an odds ratio of 0.34 for serum calcium concentration on d 3 , indicating that a multiparous cow with serum calcium concentration of $2.5 \mathrm{mmol} / \mathrm{L}$ had a $66 \%$ lower chance of developing APM compared with a cow with a concentration of $1.5 \mathrm{mmol} / \mathrm{L}$. Primiparous cows with low serum calcium concentration had the highest predicted probability of developing APM. Our results reveal a dynamic in serum calcium concentration in the first 3 $\mathrm{d}$ in milk. Consequently, the day of sampling and the observed risk period for hypocalcemia are important when conducting epidemiological studies to evaluate associations between hypocalcemia and clinical diseases. Key words: serum calcium dynamics, hypocalcemia, acute puerperal metritis, parity, dairy cow

\section{INTRODUCTION}

In the recent past, a lot of research has been conducted to evaluate the effect of periparturient hypocalcemia on the subsequent health and performance of dairy cows. While the greatest risk for hypocalcemia occurs within $48 \mathrm{~h}$ after parturition (Megahed et al., 2018), most of the epidemiological studies used a relatively wide period (e.g., first week) to evaluate the effect of hypocalcemia on health and performance in early lactation.

Chapinal et al. (2012) found that hypocalcemia $(<2.1$ $\mathrm{mmol} / \mathrm{L})$ at $1 \mathrm{wk}$ postpartum had a negative effect on milk yield $(-2.6 \mathrm{~kg}$ at first DHIA test). Seifi et al. (2011) and Roberts et al. (2012) observed 2.4 and 1.5 times greater odds for cows being culled within 60 DIM when serum calcium concentration was $\leq 2.2 \mathrm{mmol} / \mathrm{L}$ at wk 1 postpartum, respectively.

Due to the nature of blood calcium dynamics around parturition, consideration of different risk periods might influence the observed association of hypocalcemia with downstream outcomes and contribute to disagreement 
regarding the risk to health and performance associated with hypocalcemia (Chapinal et al., 2012; Jawor et al., 2012; Venjakob et al., 2018). One reason for contradictory results of recent studies might be the calcium dynamics in the first few DIM (Caixeta et al., 2017; Neves et al., 2018a). In the study by Caixeta et al. (2017), cows were classified as normocalcemic, subclinically hypocalcemic, and chronic subclinically hypocalcemic based on the number of blood samples with a serum calcium concentration $\leq 2.15 \mathrm{mmol} / \mathrm{L}$. In that study, $46 \%(\mathrm{n}=45)$ of the animals sampled recovered from subclinical hypocalcemia until 3 DIM, whereas $33(34 \%)$ were classified as chronic subclinically hypocalcemic because they were below the threshold on $\mathrm{d}$ 1 to 3 . The mechanisms to increase calcium retention in the kidneys, increase calcium absorption from the gut, and upregulate calcium release from bone are gene regulated and take at least $24 \mathrm{~h}$ to induce changes in serum calcium concentrations (Martín-Tereso and Martens, 2014). Therefore, it seems plausible that most cows with subclinical hypocalcemia on d 1 would be normocalcemic later (e.g., d 6).

In another prospective cohort study (Martinez et al., 2012), serum calcium concentration was measured on d $0,1,2,3,4,7$, and 12 after calving in cows classified as metritic or healthy. In cows with metritis, hypocalcemia was more severe and present longer than in cows without metritis. In that study, hypocalcemia was also shown to impair immune function. This observation was confirmed by a further study by the same group (Martinez et al., 2014) in which healthy cows with induced subclinical hypocalcemia had compromised appetite, altered metabolism, and impaired function of immune cells. However, Waldron et al. (2003) and Kvidera et al. (2017) demonstrated that infusion of LPS, which elicits a robust immune response, led to a decrease in serum calcium concentration. Therefore, clarification is needed on whether hypocalcemia is a cause or a concomitant circumstance of infectious diseases.

Parity is well accepted as a predominant risk factor for hypocalcemia (Reinhardt et al., 2011; Goff, 2014; Venjakob et al., 2017), but evidence is limited with regard to blood calcium dynamics differing between parities.

Therefore, the objectives of this study were to evaluate postpartum serum calcium dynamics for different parity groups of dairy cows and to evaluate the association of serum calcium concentration on $\mathrm{d} 0,1$, and 3 postpartum with the risk of developing acute puerperal metritis (APM). Our hypotheses were that parity affects serum calcium concentration on d 0,1 , and 3 after calving and that cows that develop APM have a serum calcium concentration on $\mathrm{d} 0,1$, and 3 that differs from that of cows without APM.

\section{MATERIALS AND METHODS}

\section{Study Design}

This observational study was carried out using health and production records from 1 dairy herd between April 2011 and February 2014. During this period, blood samples were collected from 4,043 cows on d 0,1 , and 3 after calving. Further records were collected from the on-farm computer system Dairy Comp 305 (Valley Ag Software, Tulare, CA). The farm is located in northern Germany and has 3,706 Holstein Friesian dairy cows including offspring. Of those cows, approximately 2,200 were lactating and had an average 305-d milk yield of $11,520 \mathrm{~kg}$.

\section{Transition Cow Management}

Heifers were moved to a close-up pen within the transition management facility (TMF) at d 264 of gestation. Cows were dried off $55 \mathrm{~d}$ before expected parturition and moved to the TMF. Cows and heifers were kept separately in sand-bedded freestall pens. Around $21 \mathrm{~d}$ before expected calving, cows and heifers were moved to separate close-up pens with a maximum of 32 animals per group. Cows and heifers in the far-off and close-up pens were fed once daily and feed was pushed up 10 times a day. Cows were closely monitored for signs of imminent calving. When the amniotic sac or the calf's feet were visible outside the vulva, animals were moved to an individual maternity pen $(3.5$ $\times 3.5 \mathrm{~m}$ ) with concrete topped with straw (just-in-time calving). Immediately after birth, the calf was separated from the dam and every cow received $500 \mathrm{~mL}$ of propylene glycol (Bernd-Dieter, Dusseldorf, Germany) administered orally in $50 \mathrm{~L}$ of warm water $\left(37-38^{\circ} \mathrm{C}\right)$. Cows and heifers were moved to 2 separate fresh cow pens with sand bedding and milked 3 times daily in a side-by-side milking parlor within the TMF. Every cow in this study was examined daily until 10 DIM by the farm personnel following standard operating procedures created by the herd management. During examinations, animals were monitored visually to assess general appearance, attitude, presence of fetal membranes outside the vulva, vaginal discharge, udder health, lameness, and manure consistency. Moreover, rectal temperature was measured and rumen motility was auscultated. Transrectal massage of the uterus was conducted daily to obtain and evaluate uterine discharge. Daily milk production was recorded to identify cows with disease. A definition of each disease of interest was provided to the farm personnel. Between d 10 and 21 after calving, cows were moved to the freestall barn and milked 3 times daily. The TMR from far-off, close-up, and fresh cows was formulated to meet or exceed minimum nu- 
Table 1. Chemical composition (\% unless otherwise noted) of prepartum and postpartum diets ${ }^{1}$

\begin{tabular}{|c|c|c|c|c|c|c|}
\hline \multirow{3}{*}{$\begin{array}{l}\text { Nutrient composition } \\
\text { (DM basis) }\end{array}$} & \multicolumn{4}{|c|}{ Prepartum diets } & \multirow{2}{*}{\multicolumn{2}{|c|}{$\begin{array}{c}\text { Postpartum diet } \\
\text { Fresh }\end{array}$}} \\
\hline & \multicolumn{2}{|c|}{ Far-off } & \multicolumn{2}{|c|}{ Close-up } & & \\
\hline & Mean & $\mathrm{SD}$ & Mean & $\mathrm{SD}$ & Mean & $\mathrm{SD}$ \\
\hline $\mathrm{CP}$ & 12.28 & 0.12 & 13.83 & 0.76 & 16.62 & 0.08 \\
\hline Ether extract & 2.90 & 0.20 & 3.05 & 0.04 & 4.90 & 0.30 \\
\hline $\mathrm{NDF}$ & 51.51 & 0.48 & 41.40 & 0.97 & 34.04 & 0.17 \\
\hline $\mathrm{NFC}^{1}$ & 26.37 & 1.28 & 34.34 & 0.91 & 37.28 & 0.01 \\
\hline Starch & 12.14 & 1.62 & 18.79 & 0.37 & 18.46 & 0.21 \\
\hline Ash & 6.95 & 0.47 & 7.39 & 0.43 & 7.16 & 0.04 \\
\hline Calcium & 0.50 & 0.01 & 1.02 & 0.07 & 0.95 & 0.07 \\
\hline Phosphorus & 0.35 & 0.03 & 0.44 & 0.06 & 0.45 & 0.03 \\
\hline Magnesium & 0.21 & 0.00 & 0.36 & 0.02 & 0.27 & 0.01 \\
\hline Sodium & 0.29 & 0.03 & 0.14 & 0.02 & 0.41 & 0.05 \\
\hline Potassium & 1.61 & 0.33 & 1.22 & 0.13 & 1.58 & 0.02 \\
\hline Chloride & 0.94 & 0.03 & 0.99 & 0.02 & 0.65 & 0.01 \\
\hline Sulfur & 0.13 & 0.04 & 0.18 & 0.06 & 0.24 & 0.02 \\
\hline $\mathrm{DCAD},{ }^{2} \mathrm{mEq} / 100 \mathrm{~g}$ & 19.39 & 6.96 & -1.71 & 0.82 & 25.21 & 3.01 \\
\hline
\end{tabular}

tritional requirements for high-producing dairy cows (Table 1; NRC, 2001).

\section{Data Collection}

All infectious and metabolic diseases occurring after calving were diagnosed based on specific protocols. The diseases monitored for in this study were retained placenta, APM, mastitis, left displaced abomasum, and clinical milk fever. Cows were diagnosed with retained placenta when fetal membranes were not expulsed until $24 \mathrm{~h}$ after calving. Cows with retained placenta were not treated, but they were monitored for pyrexia for $10 \mathrm{~d}$. Acute puerperal metritis was defined as an animal having an abnormally enlarged uterus and a fetid, watery, red-brown uterine discharge, associated with a sign of systemic illness such as decreased milk yield, dullness or other signs of toxemia, and fever $>39.5^{\circ} \mathrm{C}$ (Sheldon et al., 2006). Cows diagnosed with APM were treated with ceftiofur hydrochloride $(2.2 \mathrm{mg} / \mathrm{kg}$ of BW; Excenel RTU, Zoetis, Parsippany, NJ) intramuscularly for 3 consecutive days. In addition, the uterus was infused with oxytetracycline on the day of diagnosis (15 $\mathrm{mg} / \mathrm{kg}$ of BW; Oxy-Sleecol $200 \mathrm{LA}$, Albrecht GmbH, Aulendorf, Germany). Based on Vasquez et al. (2017), clinical mastitis was defined by visible signs of inflammation in an affected mammary gland such as redness, swelling, pain, or heat, and alterations such as clots, flakes, discoloration, or abnormal consistency of secretions. Cows were considered to have a left displaced abomasum when percussion of the left flank resulted in tympanic resonance detected using a stethoscope.
Treatment of choice was the "roll and toggle" method (Grymer and Sterner, 1982). In case of unsuccessful treatment, cows were surgically treated with abomasopexy. Clinical hypocalcemia was defined as recumbency in combination with a serum calcium concentration below $1.4 \mathrm{mmol} / \mathrm{L}$. Cows with clinical hypocalcemia were treated intravenously with $500 \mathrm{~mL}$ of a $23 \%$ calcium borogluconate solution (10.5 g of calcium).

Further parameters recorded for the study were calving ease $(0=$ physiological calving, $1=$ calving assisted by 1 person, 2 = calving assisted by 2 people, $3=$ calving assisted by more than 2 people), stillbirth (alive vs. dead), twins, calf sex, and backfat thickness (measured by ultrasound on the day of calving).

Blood samples were drawn from the coccygeal vessels on d 0 (immediately after calving), d 1 (within $24 \mathrm{~h}$ after calving, at $0800 \mathrm{~h}$ on the following day), and $\mathrm{d}$ 3 (within 48-72 $\mathrm{h}$ after calving on the third day after calving at $0800 \mathrm{~h}$ ) using a serum blood collection system including a sterile needle (Sterican, 1,20 × $40 \mathrm{~mm}$, B. Braun Melsungen AG, Melsungen, Germany) and a serum blood tube (Monovette $9 \mathrm{~mL} \mathrm{Z}$, Sarstedt AG \& Co., Nümbrecht, Germany). Blood samples were kept at room temperature for about $30 \mathrm{~min}$ to clot. Subsequently, samples were centrifuged at $2,000 \times g$ for 20 min to harvest serum (Heraeus Sepatech Labofuge 200, Heraeus Holding GmbH, Hanau, Germany). Serum was transferred into 5-mL tubes ( $5 \mathrm{~mL}$ Röhrchen, Sarstedt AG \& Co.), using a pipette (Transferpipette $3.5 \mathrm{~mL}$, Sarstedt AG \& Co.) and frozen at $-20^{\circ} \mathrm{C}$.

Serum samples were analyzed in the laboratory of the ruminant clinic, Freie Universität Berlin. Serum calcium 
concentration was determined using atomic absorption spectroscopy (AAS-Spektrometer Solar M6, Thermo Fisher Scientific GmbH, Berlin, Germany). Phosphorus was measured using enzymatic methods (Cobas Mira Plus, Roche Diagnostics International AG, Rotkreuz, Switzerland). $\beta$-Hydroxybutyrate and nonesterified fatty acids (NEFA) were measured using enzymatickinetic and colorimetric methods, respectively (Cobas Mira Plus, Roche Diagnostics International AG, Rotkreuz, Switzerland). The interassay coefficient of variation was 3.94\% (Ca $2.37 \mathrm{mmol} / \mathrm{L} ; \mathrm{n}=10), 1.92 \%(P=$ $1.43 \mathrm{mmol} / \mathrm{L} ; \mathrm{n}=10), 9.49 \%(\mathrm{BHB}=0.92 \mathrm{mmol} / \mathrm{L} ; \mathrm{n}$ $=195)$, and $7.75 \%(\mathrm{NEFA}=0.44 \mathrm{mmol} / \mathrm{L} ; \mathrm{n}=195)$ for calcium, phosphorus, BHB, and NEFA, respectively. The intraassay coefficient of variation was $1.26 \%$ (Ca $2.33 \mathrm{mmol} / \mathrm{L} ; \mathrm{n}=10), 1.25 \%(\mathrm{P}=1.41 \mathrm{mmol} / \mathrm{L} ; \mathrm{n}=$ $10), 1.22 \%(\mathrm{BHB}=0.93 \mathrm{mmol} / \mathrm{L} ; \mathrm{n}=10)$, and $1.11 \%$ $(\mathrm{NEFA}=0.46 \mathrm{mmol} / \mathrm{L} ; \mathrm{n}=10)$ for calcium, phosphorus, BHB, and NEFA, respectively.

\section{Statistical Analyses}

Individual cow data were transferred to Excel (Office 2013; Microsoft Deutschland Ltd., Munich, Germany). Statistical analyses were performed using SPSS for Windows (version 22.0; SPSS Inc., Chicago, IL).

To evaluate serum calcium dynamic within the first 3 DIM, a repeated measures ANOVA with first-order autoregressive covariance was performed using the GENLINMIXED procedure of SPSS. The outcome variable was serum calcium concentration $(\mathrm{mmol} / \mathrm{L})$. Cow was the experimental unit. Parity was used as a repeated measure to account for the fact that observations from cows that were enrolled repeatedly in different years were not independent from each other. According to the model-building strategies described by Dohoo et al. (2009), each parameter considered for the mixed model was separately analyzed in a univariable model. Only parameters resulting in univariable models with $P \leq$ 0.10 were included in the final mixed model. Selection of the model that best fit the data was performed by using a backward stepwise elimination procedure that removed all variables with $P>0.10$ from the model. Regardless of the significance level, calcium status was forced to remain in the model. The initial model contained time (blood sample on d 0, 1, and 3), parity (lactation 1, 2, 3, and $\geq 4$ ), and APM (yes vs. no) as explanatory variables as fixed effects. We tested all biological plausible interactions such as time $\times$ parity, time $\times \mathrm{APM}$, and time $\times$ parity $\times \mathrm{APM}$.

We evaluated the association of serum calcium concentration on d 0,1 , or 3 with the probability of developing APM by using a logistic regression model with the GENLINMIXED procedure of SPSS. To avoid au- tocorrelation between the 3 sampling time points, separate models were built for serum calcium concentration on d 0,1 , and 3, respectively. Moreover, for each day, separate models were built for primiparous and multiparous cows. Cow was again the experimental unit. In all models of multiparous cows, parity was used as a repeated measure to account for the fact that observations from the same cows that were enrolled repeatedly in different years were not independent from each other. Model building was conducted as described for the model above. The initial models for multiparous cows contained the following explanatory variables: parity (lactation $2,3, \geq 4$ ), twins (yes vs. no), retained placenta (yes vs. no), month of freshening (January-December), NEFA on d 3 (continuous), stillbirth (yes vs. no), and backfat thickness on d 0 (continuous) and either serum calcium concentration on d 0,1 , or 3 (continuous). The initial models for primiparous cows contained the same explanatory variables except for parity. Regardless of the significance level, serum calcium concentration was forced to remain in the model. Predicted probabilities were calculated using the final model to illustrate the association between serum calcium concentration and the risk to develop APM.

To identify cows with subsequent APM based on their serum calcium concentration on d 3 after calving a receiver operating characteristic (ROC) analysis was performed using MedCalc for Windows (version 12.0.3.0., MedCalc Software bvba, Mariakerke, Belgium). To account for the different serum calcium dynamics for cows in parity $1,2,3$, and $\geq 4$, ROC analysis was performed separately for each parity group. The continuous variable was serum calcium concentration on $\mathrm{d} 3$, and the classification variable was APM. The ROC curves compare sensitivity with 100 - specificity. The point on the ROC curve with the highest combined sensitivity and specificity was considered as the optimum threshold. Interpretation of this threshold was based on the area under the curve (AUC) according to Swets (1988) as noninformative $(\mathrm{AUC}=0.5)$, accurate $(0.5<\mathrm{AUC} \leq 0.7)$, very accurate $(0.7<\mathrm{AUC} \leq 0.9)$, highly accurate $(0.9<\mathrm{AUC}<1)$, and perfect $(\mathrm{AUC}$ $=1$ ).

Exclusion criteria were clinical milk fever, APM before 4 DIM, or incomplete data sets (e.g., missing blood sample).

\section{RESULTS}

A total of 4,043 animals were included in this study. After exclusion of 406 animals (10.0\%) due to developing clinical milk fever $(\mathrm{n}=88)$ around parturition, APM before 4 DIM $(\mathrm{n}=31)$, or incomplete data sets $(\mathrm{n}$ $=287$ ), 3,637 animals were available for final statistical 
analyses. Of those 1,053 (28.9\%), 1,080 (29.7\%), 650 $(17.9 \%)$, and $854(23.5 \%)$ were in lactation $1,2,3$, and $\geq 4$, respectively.

\section{Serum Calcium Dynamics}

Serum calcium concentration was affected by time $(P$ $=0.003)$, parity $(P<0.001)$, and $\mathrm{APM}(P=0.005)$. Interactions were observed for time $\times$ parity $(P<$ $0.001)$, time $\times \operatorname{APM}(P<0.001)$, and time $\times$ parity $\times$ APM $(P=0.060)$. These interactions are summarized in Figures 1 and 2. Mean serum calcium concentration 0 to 3 DIM was $2.17,2.13,2.06$, and $1.99 \mathrm{mmol} / \mathrm{L}$ for cows with parity $1,2,3$, and $\geq 4$, respectively. The nadir of serum calcium concentration occurred on $\mathrm{d}$ 1 and 3 after calving in multiparous and primiparous cows, respectively. While serum calcium concentration increased in multiparous cows from d 1 to d 3, serum calcium concentration decreased throughout sampling time in primiparous cows (Figure 1). The association of APM and serum calcium dynamics was conditional on parity. Overall, on d 3 serum calcium concentration was significantly lower $(P<0.001)$ in animals with subsequent APM than in cows without APM.

\section{Associated Risk of APM}

The overall incidence of APM was $12.0 \%(438 / 3,637)$. The incidence of APM was 20.4\% $(215 / 1,053)$ and $8.6 \%$ $(223 / 2,584)$ in primiparous and multiparous cows, respectively. To evaluate the association between serum calcium concentration and susceptibility to APM, separate models were built for primiparous and multiparous cows based on serum calcium concentration on d 0,1 , and 3. While serum calcium concentration on d 0 (primiparous: $P=0.160$; multiparous: $P=0.112)$ and $\mathrm{d} 1$ (primiparous: $P=0.228$; multiparous: $P=0.061$ ) was not associated with APM, an association was found between serum calcium concentration on 3 DIM and susceptibility to APM (Tables 2, 3, and 4). Primiparous cows had an odds ratio $(\mathbf{O R})$ of $0.12(P<0.001)$ for serum calcium concentration on $\mathrm{d} 3$, indicating that a primiparous cow with a serum calcium concentration of $2.5 \mathrm{mmol} / \mathrm{L}$ had a $88 \%$ lower chance of being diagnosed with APM compared with a cow with a serum calcium concentration of $1.5 \mathrm{mmol} / \mathrm{L}$. Multiparous cows had an OR of $0.34(P<0.001)$ for serum calcium concentration on $\mathrm{d} 3$, indicating that a multiparous cow with a serum calcium concentration of $2.5 \mathrm{mmol} / \mathrm{L}$ had a $66 \%$ lower chance of being diagnosed with APM compared with a cow with a concentration of $1.5 \mathrm{mmol} / \mathrm{L}$. Furthermore, in the model for primiparous cows retained placenta $(P<0.001)$, month of freshening $(P<0.001)$, stillbirth $(P=0.046)$, and backfat thickness on the



Figure 1. Serum calcium concentration $(\mathrm{mmol} / \mathrm{L})$ within the first 3 DIM for cows $(\mathrm{n}=3,637)$ in parity $1(\mathrm{n}=1,053$; solid line $), 2(\mathrm{n}=$ 1,080 ; dotted line), 3 ( $\mathrm{n}=650$; short-dashed line), and $\geq 4(\mathrm{n}=854$; long-dashed line) using least squares estimates (mean \pm SEM) from repeated measure ANOVA. Time $(P=0.003)$, parity $(P<0.001)$, acute puerperal metritis (APM, $P=0.005)$, time $\times$ parity $(P=0.001)$, and time $\times \operatorname{APM}(P<0.001)$ affected serum calcium concentration significantly. A tendency was observed for time $\times$ APM $\times$ parity to affect serum calcium concentration $(P=0.060)$.

day of calving $(P=0.001)$ were significantly associated with the probability of developing APM (Table 3). In the model for multiparous cows, retained placenta $(P$ $<0.001)$, parity $(P<0.001)$, month of freshening $(P<$ $0.001)$, and twins $(P=0.001)$ were significantly associated with the probability of developing APM (Table 4). Primiparous cows with low serum calcium concentration had the highest predicted probability of developing APM (Figure 3).

Serum calcium concentration was analyzed for each lactation group using ROC curves to determine the optimum thresholds (combined highest sensitivity and specificity) to identify cows with subsequent APM. The AUC was $0.69(P<0.001), 0.64(P<0.001), 0.61(P=$ $0.005)$, and $0.59(P=0.006)$ for cows in lactation 1,2 , 3 , and $\geq 4$, respectively (Table 5 ).

\section{DISCUSSION}

The objectives of this study were to evaluate postpartum serum calcium dynamics for different parity groups of dairy cows and to evaluate the association of serum calcium concentration on d 0,1 , and 3 postpartum with the risk of developing APM.

We observed an association between parity and serum calcium dynamics from d 0 to 3 (Figure 1). Based on 


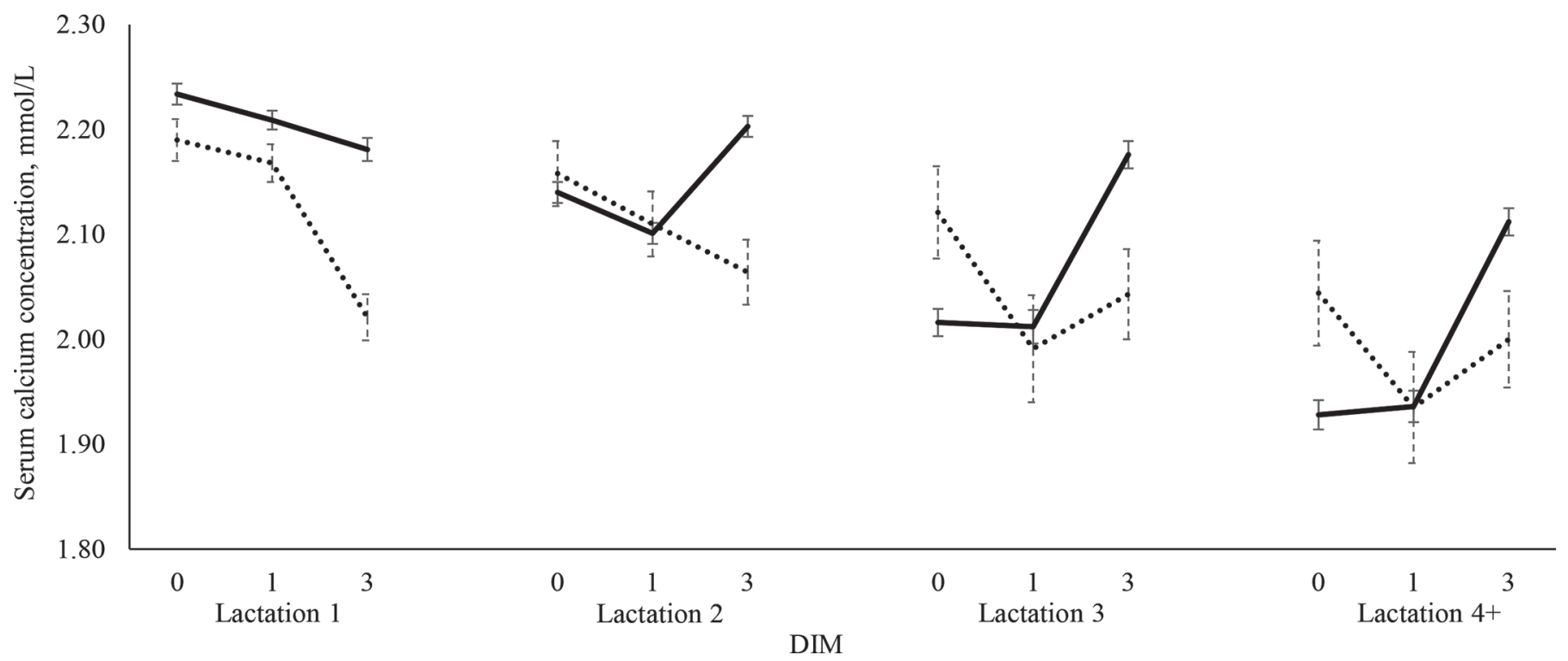

Figure 2. Association of acute puerperal metritis (APM) and serum calcium concentration (mmol/L) within the first 3 DIM stratified by parity. Least square estimates (mean \pm SEM) were used from the generalized linear mixed model. The solid lines represent cows without APM, whereas the dotted lines represent cows with APM. Among cows in parity 1, 2, 3, and $\geq 4,20.4 \%(215 / 1,053), 9.9 \%(107 / 1,080), 8.0 \%(52 / 650)$, and $7.5 \%(64 / 854)$ experienced APM, respectively. Time $(P=0.003)$, parity $(P<0.001)$, APM $(P=0.005)$, time $\times$ parity $(P<0.001)$, and time $\times \operatorname{APM}(P<0.001)$ affected serum calcium concentration significantly. A tendency was observed for time $\times$ APM $\times$ parity to affect serum calcium concentration $(P=0.060)$.

single samples around parturition, it has been consistently shown that primiparous cows are less susceptible to developing hypocalcemia (Reinhardt et al., 2011; Miltenburg, 2015; Venjakob et al., 2017). Prevalence of hypocalcemia in primiparous cows ranged from $2 \%$ (Miltenburg, 2015) and 5.7\% (Venjakob et al., 2017) to $25 \%$ (Reinhardt et al., 2011), considering a threshold serum calcium concentration of $2.0 \mathrm{mmol} / \mathrm{L}$. Based on this threshold, overall incidence of hypocalcemia was $33.9 \%(357 / 1,053)$ in the present study. With regard to specific days, the calculated prevalence was comparable to the aforementioned studies $[9.4 \%(99 / 1,053), 10.5 \%$ $(111 / 1,053)$, and $23.6 \%(248 / 1,053)$ for $\mathrm{d} 0,1$, and 3 after calving, respectively]. Cows in their first lactation are commonly assumed to be able to mobilize calcium from bone tissue more rapidly than cows in later lactations because more active osteoclasts and osteoblasts are available due to their immature skeleton (Goff, 2014). This assumption is supported by previous work conducted by Kamiya et al. (2005) and Taylor et al.

Table 2. Serum calcium concentration within the first 3 DIM $(\mathrm{n}=3,637)$ and the associated risk of acute puerperal metritis $(A P M)$

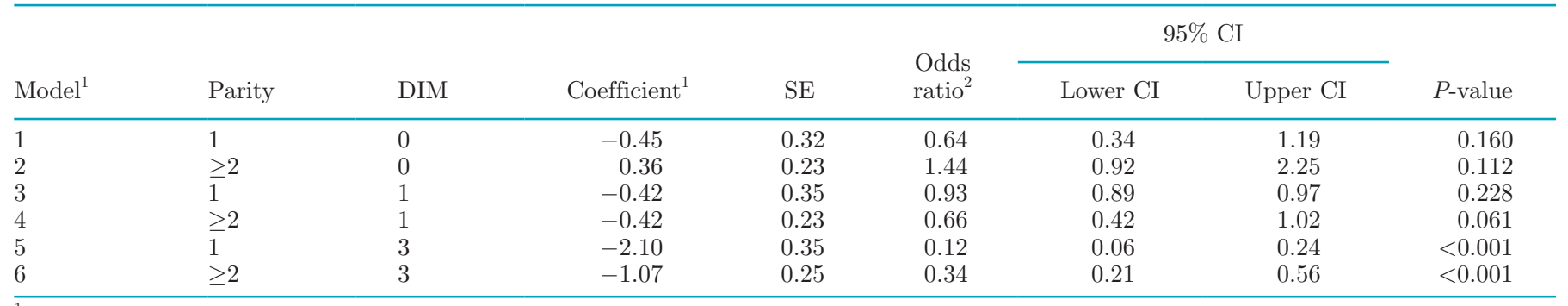

${ }^{1}$ Model 1 included retained placenta $(P<0.001)$, month of freshening $(P=0.001)$, backfat thickness on the day of calving $(P=0.002)$, stillbirth $(P=0.047)$, and serum nonesterified fatty acids (NEFA) concentration on d $3(P=0.071)$ as fixed effects. Model 2 included parity $(P$ $<0.001)$, retained placenta $(P<0.001)$, month of freshening $(P=0.001)$, and twins $(P<0.001)$ as fixed effects. Model 3 included retained placenta $(P<0.001)$, month of freshening $(P=0.001)$, backfat thickness on the day of calving $(P=0.002)$, stillbirth $(P=0.040)$, and NEFA on d $3(P=0.046)$ as fixed effects. Model 4 included parity $(P=0.026)$, retained placenta $(P<0.001)$, month of freshening $(P=0.001)$, and twins $(P=0.005)$ as fixed effects. Model 5 included retained placenta $(P<0.001)$, month of freshening $(P<0.001)$, stillbirth $(P=0.046)$, and backfat thickness on the day of calving $(P=0.001)$ as fixed effects. Model 6 included parity $(P<0.001)$, retained placenta $(P<0.001)$, month of freshening $(P<0.001)$, and twins $(P<0.001)$ as fixed effects.

${ }^{2} \mathrm{An}$ odds ratio of 0.12 for serum calcium concentration on d 3 indicates that a primiparous cow with serum calcium concentration of $2.5 \mathrm{mmol} / \mathrm{L}$ had an $88 \%$ lower chance of being diagnosed with APM compared with a cow that had a serum calcium concentration of $1.5 \mathrm{mmol} / \mathrm{L}$. 
Table 3. Final multivariable logistic regression model evaluating the association of serum calcium concentration on $\mathrm{d} 3$ after calving with subsequent risk of acute puerperal metritis $(\mathrm{APM})$ in primiparous cows $(\mathrm{n}=1,053)$

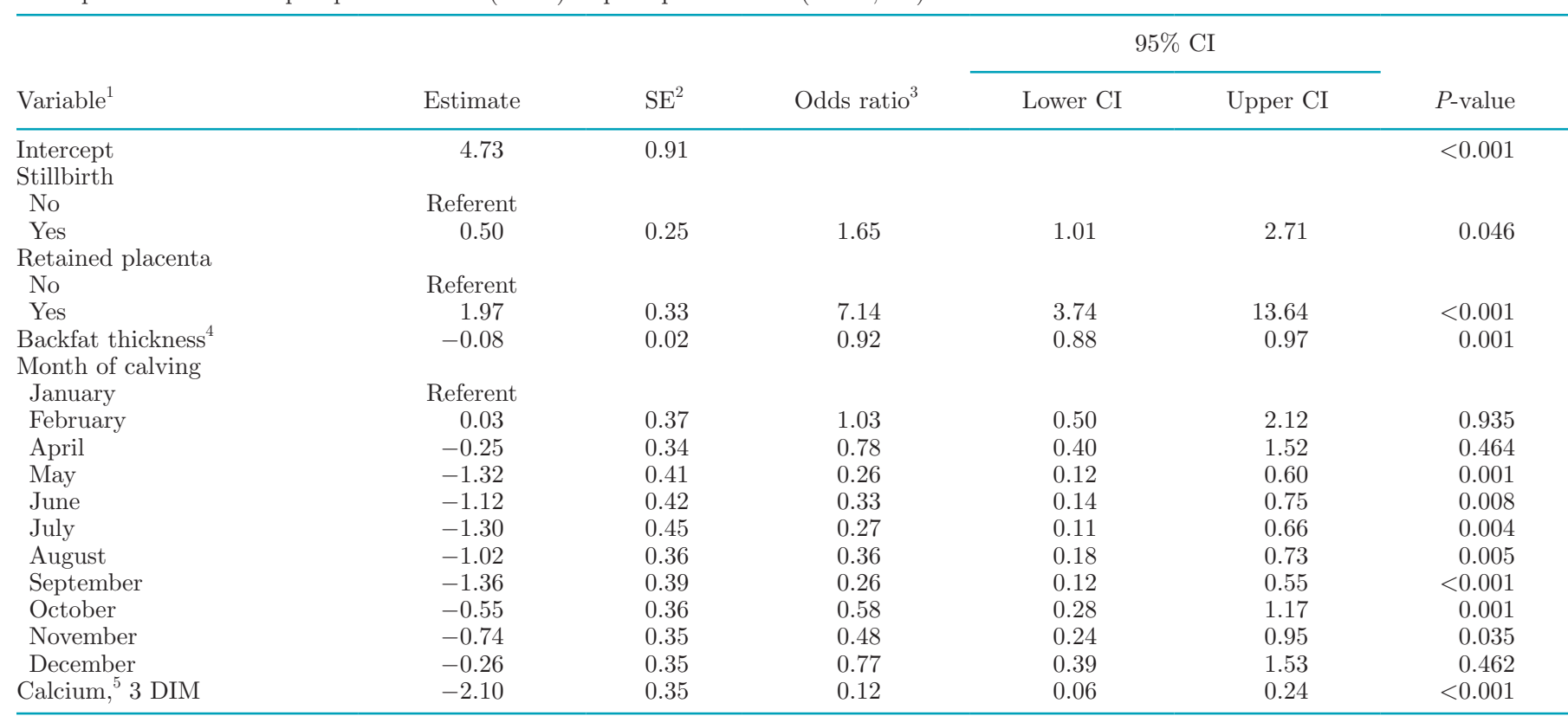

${ }^{1}$ The experimental unit was cow.

${ }^{2} \mathrm{SE}=$ standard error of the estimate.

${ }^{3}$ An odds ratio of 0.12 for serum calcium concentration on $\mathrm{d} 3$ indicates that a primiparous cow with serum calcium concentration of $2.5 \mathrm{mmol} / \mathrm{L}$ had an $88 \%$ lower chance of being diagnosed with APM compared with a cow that had a serum calcium concentration of $1.5 \mathrm{mmol} / \mathrm{L}$.

${ }^{4}$ Backfat thickness was measured on the day of calving.

${ }^{5}$ Serum calcium concentration measured on d 3 after calving.

(2009). Both groups of authors were able to show that primiparous cows had significantly higher concentrations of osteocalcin and deoxypyridinoline, markers of bone formation and resorption, which indicated that bone turnover is greater in primiparous cows than in multiparous cows. In our study, serum calcium concentration over time developed differently in primiparous cows compared with multiparous cows. Whereas multiparous cows had their nadir in serum calcium dynamics on d 1 and increased until d 3, primiparous cows reached their nadir $2 \mathrm{~d}$ later. The reason remains speculative, however, a greater portion of primiparous cows developed subsequent APM, which might explain the decrease in serum calcium concentration from $d 1$ to 3 .

The results of our study show that serum calcium dynamics differ not only between primiparous and multiparous cows, but also between parity groups among multiparous cows. In all multiparous cows, however, the nadir of serum calcium concentration was observed on d 1. Megahed et al. (2018) characterized plasma calcium concentration of multiparous cows around calving. They found that mean plasma calcium concentration of multiparous cows $(\mathrm{n}=70)$ dropped around parturition and recovered until $48 \mathrm{~h}$ after calving. The lowest plasma calcium concentration occurred $28 \mathrm{~h}$ after calving. These data are in agreement with Martinez et al. (2012), who observed the nadir in serum calcium concentration on d 2. Given the considerable changes in serum calcium concentration in the first few DIM, the day of calcium assessment is important in determining prevalence of hypocalcemia (Neves et al., 2018a). In the present study, serum calcium concentration was not assessed on d 2 after calving. Therefore, our data do not allow drawing any inference about the optimal day to evaluate the prevalence of hypocalcemia.

Overall, the incidence of APM of the study herd was $12.0 \%$, which is in agreement with other studies (Giuliodori et al., 2013; Pohl et al., 2016). With regard to parity, $20.4 \%$ and $8.6 \%$ of primiparous and multiparous cows experienced APM, respectively. Other studies (Giuliodori et al., 2013; Neves et al., 2018a) have also described a higher incidence of APM in primiparous cows. Risk factors for APM, however, are plentiful and include parity, increased NEFA concentration prepartum, dystocia, stillbirth, vulvovaginal laceration, retained placenta and increased haptoglobin concentration in the first week postpartum (Dubuc et al., 2010; Giuliodori et al., 2013; Pohl et al., 2015; Vieira-Neto et al., 2016). 
Serum calcium dynamics were altered in cows with subsequent APM compared with healthy cows (Figure 2 ) and were associated with APM on d $3(P=0.001$ for primiparous and multiparous cows). Previous results on the association between hypocalcemia on $\mathrm{d} 0$ and the risk of subsequent APM are conflicting. Plasma calcium concentrations measured within $12 \mathrm{~h}$ after calving were not associated with the risk of APM (Neves et al., 2018b). In addition, Chamberlin et al. (2013) did not detect an association between hypocalcemia on $\mathrm{d} 0$ or 3 and APM risk. In their study, blood samples from 100 cows were taken and analyzed for blood ionized calcium. An association between hypocalcemia and APM could not be detected; however, the study was underpowered, with only 8 out of 100 cows developing APM.

In contrast to the results, hypocalcemic cows were found to have a higher risk of developing metritis, specifically, $25.1 \%$ of cows with a serum calcium concentration $\leq 2.0 \mathrm{mmol} / \mathrm{L}$ within $2 \mathrm{~h}$ postpartum versus $14.7 \%$ in normocalcemic cows (Wilhelm et al., 2017). Also, Rodríguez et al. (2017) found cows had 4.25 greater odds for developing metritis when serum calcium concentration was $\leq 2.14 \mathrm{mmol} / \mathrm{L}$ at 24 to $48 \mathrm{~h}$ after calving. Neves et al. (2018a) found an association between serum calcium concentration on d 2, 3, and 4 after calving and subsequent APM in primiparous cows. Performing ROC curve analyses, these authors found a comparable cut point of $2.10 \mathrm{mmol} / \mathrm{L}$. Evaluating the association between serum calcium concentration and APM in multiparous cows, Neves et al. (2018a) found an association between serum calcium concentration on d 2 and APM in cows in lactation 2, and serum calcium concentration on $\mathrm{d} 4$ and APM in cows in lactation $\geq 3$. In contrast, in the present study serum calcium concentration on d 3 was associated with the risk of developing metritis in multiparous cows. However, the AUC was not sufficient to use serum calcium determination on $\mathrm{d} 3$ as a diagnostic test for APM in primiparous or multiparous cows (Table 5).

The peak incidence of APM is known to occur at 5 to 7 DIM (Galvão, 2012). To analyze the association between hypocalcemia on $\mathrm{d} 0,1$, and 3 and the risk of developing APM, we excluded cases of APM that occurred before 4 DIM from this study. However, the association of serum calcium concentration was more pronounced with decreasing intervals between serum calcium assessment and diagnosis of APM. Therefore, a topic for consideration is whether hypocalcemia is a

Table 4. Final multivariable logistic regression model evaluating the association of serum calcium concentration on d 3 after calving with subsequent risk of acute puerperal metritis (APM) in multiparous cows $(\mathrm{n}=2,584)$

\begin{tabular}{|c|c|c|c|c|c|c|}
\hline Variable $^{1}$ & Estimate & $\mathrm{SE}^{2}$ & Odds ratio $^{3}$ & \multicolumn{2}{|c|}{$95 \% \mathrm{CI}$} & $P$-value \\
\hline \multicolumn{7}{|l|}{ Parity } \\
\hline Lactation 2 & Referent & & & & & \\
\hline Lactation 3 & -0.18 & 0.20 & 0.84 & 0.57 & 1.24 & 0.375 \\
\hline Lactation $\geq 4$ & -1.14 & 0.23 & 0.32 & 0.20 & 0.50 & $<0.001$ \\
\hline Yes & 1.05 & 0.26 & 2.86 & 1.72 & 4.76 & $<0.001$ \\
\hline \multicolumn{7}{|l|}{ Retained placenta } \\
\hline No & Referent & & & & & \\
\hline Yes & 3.35 & 0.22 & 28.55 & 18.60 & 43.83 & $<0.001$ \\
\hline \multicolumn{7}{|l|}{ Month of calving } \\
\hline January & Referent & & & & & \\
\hline February & -1.39 & 0.39 & 0.25 & 0.12 & 0.53 & $<0.001$ \\
\hline September & -1.12 & 0.36 & 0.33 & 0.16 & 0.66 & 0.002 \\
\hline October & -1.16 & 0.35 & 0.31 & 0.16 & 0.62 & 0.001 \\
\hline November & -0.73 & 0.31 & 0.48 & 0.26 & 0.89 & 0.019 \\
\hline December & -0.79 & 0.31 & 0.45 & 0.25 & 0.83 & 0.011 \\
\hline Calcium, 3 DIM $^{4}$ & -1.07 & 0.25 & 0.34 & 0.21 & 0.56 & $<0.001$ \\
\hline
\end{tabular}

${ }^{1}$ The experimental unit was cow. To account for cows that were included multiple times in different years, parity was used as repeated measure. ${ }^{2} \mathrm{SE}=$ standard error of the estimate.

${ }^{3} \mathrm{An}$ odds ratio of 0.34 for serum calcium concentration on $\mathrm{d} 3$ indicates that a multiparous cow with serum calcium concentration of 2.5 mmol/L had a $66 \%$ lower chance of being diagnosed with APM compared with a cow that had a serum calcium concentration of $1.5 \mathrm{mmol} / \mathrm{L}$.

${ }^{4}$ Serum calcium concentration measured on d 3 after calving. 


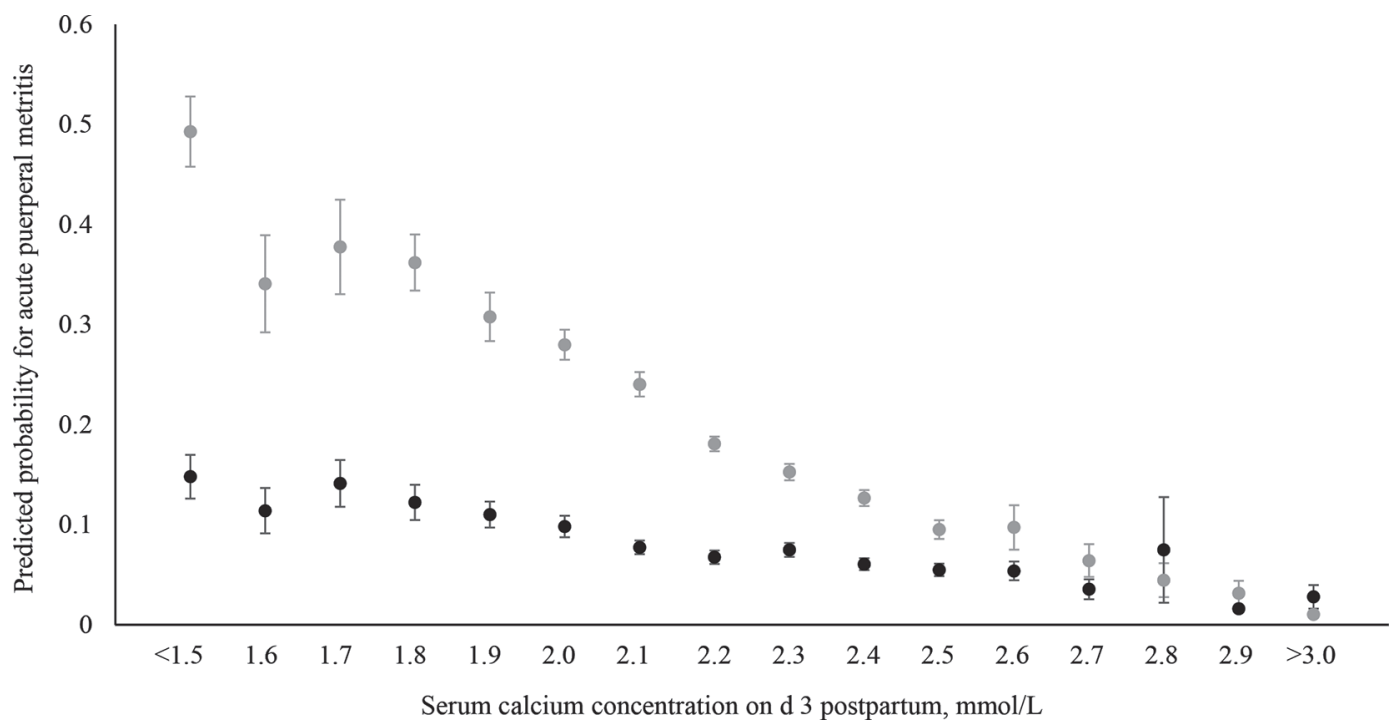

Figure 3. Predicted probability $( \pm$ SEM) of acute puerperal metritis based on serum calcium concentration on d 3 using increments of 0.1 $\mathrm{mmol} / \mathrm{L}$ stratified by parity (gray symbols $=$ parity $1, \mathrm{n}=1,053$; black symbols $=$ parity $\geq 2, \mathrm{n}=2,584$ ) using predicted probabilities from the generalized linear mixed model. The model of primiparous cows included retained placenta $(P<0.001)$, month of freshening $(P<0.001)$, stillbirth $(P=0.046)$, backfat thickness on the day of calving $(P=0.001)$, and serum calcium concentration on d $3(P<0.001)$ as fixed effects. The model of multiparous cows included parity $(P<0.001)$, retained placenta $(P<0.001)$, month of freshening $(P<0.001)$, twins $(P<0.001)$, and serum calcium concentration on d $3(P<0.001)$ as fixed effects.

risk factor for APM or a concomitant circumstance of the disorder.

The possibility that hypocalcemia increases the risk of infectious diseases is plausible because immune cell activation is reduced in cows with limited availability of calcium, as shown by Kimura et al. (2006). They obtained peripheral mononuclear cells from multiparous cows. Following an activating stimulus, calcium release from intracellular calcium stores was decreased in cows with clinical milk fever compared with hypocalcemic animals without clinical signs of the disease. Intracellular calcium release normalized as the plasma calcium concentration recovered. Further evidence was provided by Martinez et al. (2012) in an analysis of the proportion of neutrophils undergoing phagocytosis and oxidative burst in cows sampled on d 0,1 , and 3 after calving. Phagocytic activity and the percentage of neutrophils with oxidative burst were decreased in cows with subclinical hypocalcemia (serum calcium concen- tration $\leq 2.15 \mathrm{mmol} / \mathrm{L}$ ) compared with normocalcemic cows. Furthermore, the number of neutrophils was significantly reduced in cows with subclinical hypocalcemia, whereas the number of lymphocytes did not differ.

Still, the possibility also exists that hypocalcemia might be a concomitant circumstance of APM. Animals that develop APM may have reduced feed intake (Huzzey et al., 2007) and therefore reduced serum calcium concentration before clinical sign and diagnosis of the disease (Pinedo et al., 2017). Moreover, Waldron et al. (2003) found that infusion with LPS, a cell wall component of gram-negative bacteria that causes immune activation, led to a reduction in serum calcium concentration. In that study, cows were assigned to 1 of 3 treatment groups or to a control group. Animals in the treatment groups received LPS at 3 different dosages $(0.5,1.0$, or $1.5 \mu \mathrm{g} / \mathrm{kg}$ of $\mathrm{BW})$. The effect on serum calcium concentration was dose dependent, and cows receiving a higher dosage of LPS tended to have a

Table 5. Test characteristics for serum calcium concentration on d 3 after calving ( $\mathrm{mmol} / \mathrm{L})$ to identify cows with subsequent diagnosis of acute puerperal metritis (APM)

\begin{tabular}{lcccccc}
\hline Parity & $\mathrm{n}$ & Threshold $^{1}$ & AUC $^{2}(95 \% \mathrm{CI})$ & $P$-value & Sensitivity & Specificity \\
\hline 1 & 1,054 & 2.18 & $0.69(0.66-0.72)$ & $<0.001$ & 84.7 & 47.0 \\
2 & 1,080 & 2.07 & $0.64(0.61-0.67)$ & $<0.001$ & 51.4 & 69.6 \\
3 & 650 & 2.16 & $0.61(0.57-0.65)$ & 0.005 & 54.8 \\
$\geq 4$ & 854 & 2.34 & $0.59(0.56-0.62)$ & 0.006 & 93.5 & 25.9 \\
\hline
\end{tabular}

${ }^{1}$ Optimal threshold was determined by receiver operating characteristic curve analysis using the threshold with the highest sum of sensitivity and specificity to identify cows developing APM.

${ }^{2} \mathrm{AUC}=$ area under the curve. 
greater decline in serum calcium concentration. Kvidera et al. (2017) confirmed that LPS administration affected calcium homeostasis. In their study, LPS infusion led to a $46 \%$ reduction of blood-ionized calcium. These findings might explain why Pinedo et al. (2017) found significantly lower serum calcium concentrations in cows with APM on the day of diagnosis compared with matched healthy cows. Interestingly, oral calcium supplementation on the day of APM diagnosis had no positive effect on health and performance in their study.

To our knowledge, our study is the first to evaluate postpartum serum calcium dynamics and the associated risk for APM in a large number of cows. As mentioned by Neves et al. (2018a), calcium dynamics among primiparous and multiparous cows in the postpartum period have not yet been sufficiently characterized.

\section{Study Limitations}

Despite the sample size of 3,637 cows, external validity of our study is limited because it was conducted on a single commercial dairy farm. In addition, no blood sample was collected on d 2 after calving, so our data do not allow drawing any inference about the optimal day to evaluate the prevalence of hypocalcemia. Every cow enrolled in this study received $500 \mathrm{~mL}$ of propylene glycol orally at parturition. It might be possible that the treatment affected serum BHB or serum NEFA concentrations, or both, as shown previously (Mann et al., 2017). However, we are not aware of any evidence suggesting an effect of oral treatment with propylene glycol on serum calcium concentration (Mann et al., 2017). Diagnosis of fresh cow diseases was conducted according to standard operating procedures based on current literature by farm personnel. Acute puerperal metritis is one of the most inconsistently diagnosed and recorded diseases on commercial dairy farms (Kelton et al., 1998; Sannmann et al., 2012). The challenges with metritis diagnosis include inconsistent definition of metritis, inconsistent diagnostic approaches, and variations in DIM when the disease evaluations are performed (Espadamala et al., 2016). These challenges were addressed by standard operating procedures, consistent timing of diagnosis, and employee training. However, we cannot preclude that false-negative or false-positive diagnoses occurred and somehow biased the results. Such challenges cannot be avoided, and former studies encountered similar problems.

\section{CONCLUSIONS}

The present study demonstrated that dynamics in serum calcium concentration vary in the first few days of lactation depending on parity. Serum calcium con- centration in the first 3 DIM differed not only between primiparous and multiparous cows, but also between parity groups among multiparous cows. An association was found between serum calcium concentration on $\mathrm{d}$ 3 after calving and APM. Primiparous cows with a low serum calcium concentration had the highest probability of developing APM. It cannot be elucidated, however, whether hypocalcemia is a risk factor for APM or a concomitant circumstance of the disease. Further research is warranted to evaluate if parity-specific thresholds for hypocalcemia are needed. Clarification is also needed on whether hypocalcemia is a risk factor for early lactation infectious diseases or an associated symptom of inflammatory diseases.

\section{ACKNOWLEDGMENTS}

The study was funded by the Ruminant and Swine Clinic, University of Berlin (Germany). The authors are grateful to the owners and employees of the collaborating dairy farm for granting access to their facilities, cows, and herd records and their kind support.

\section{REFERENCES}

Caixeta, L. S., P. A. Ospina, M. B. Capel, and D. V. Nydam. 2017. Association between subclinical hypocalcemia in the first 3 days of lactation and reproductive performance of dairy cows. Theriogenology 94:1-7.

Chamberlin, W. G., J. R. Middleton, J. N. Spain, G. C. Johnson, M. R. Ellersieck, and P. Pithua. 2013. Subclinical hypocalcemia, plasma biochemical parameters, lipid metabolism, postpartum disease, and fertility in postparturient dairy cows. J. Dairy Sci. 96:7001-7013.

Chapinal, N., M. E. Carson, S. J. LeBlanc, K. E. Leslie, S. Godden, M. Capel, J. E. Santos, M. W. Overton, and T. F. Duffield. 2012. The association of serum metabolites in the transition period with milk production and early-lactation reproductive performance. J. Dairy Sci. 95:1301-1309.

Dohoo, P. J., S. W. Martin, and H. Stryhn. 2009. Veterinary Epidemiologic Research. 2nd ed. University of Prince Edward Island, Charlottetown, PEI, Canada.

Dubuc, J., T. F. Duffield, K. E. Leslie, J. S. Walton, and S. J. LeBlanc. 2010. Risk factors for postpartum uterine diseases in dairy cows. J. Dairy Sci. 93:5764-5771.

Espadamala, A., P. Pallares, A. Lago, and N. Silva-Del-Rio. 2016. Fresh-cow handling practices and methods for identification of health disorders on 45 dairy farms in California. J. Dairy Sci. 99:9319-9333.

Galvão, K. N. 2012. Postpartum uterine diseases in dairy cows. Anim. Reprod. 9:290-296.

Giuliodori, M. J., R. P. Magnasco, D. Becu-Villalobos, I. M. LacauMengido, C. A. Risco, and R. L. de la Sota. 2013. Metritis in dairy cows: Risk factors and reproductive performance. J. Dairy Sci. 96:3621-3631.

Goff, J. P. 2014. Calcium and magnesium disorders. Vet. Clin. North Am. Food Anim. Pract. 30:359-381.

Grymer, J., and K. E. Sterner. 1982. Percutaneous fixation of left displaced abomasum, using a bar suture. J. Am. Vet. Med. Assoc. 180:1458-1461.

Huzzey, J. M., D. M. Veira, D. M. Weary, and M. A. von Keyserlingk. 2007. Prepartum behavior and dry matter intake identify dairy cows at risk for metritis. J. Dairy Sci. 90:3220-3233. 
Jawor, P. E., J. M. Huzzey, S. J. LeBlanc, and M. A. von Keyserlingk. 2012. Associations of subclinical hypocalcemia at calving with milk yield, and feeding, drinking, and standing behaviors around parturition in Holstein cows. J. Dairy Sci. 95:1240-1248.

Kamiya, Y., M. Kamiya, M. Tanaka, and S. Shioya. 2005. Effect of calcium intake and parity on plasma minerals and bone turnover around parturition. Anim. Sci. J. 76:325-330.

Kelton, D. F., K. D. Lissemore, and E. M. Rochelle. 1998. Recommendations for recording and calculating the incidence of selected clinical diseases of dairy cattle. J. Dairy Sci. 81:2502-2509.

Kimura, K., T. A. Reinhardt, and J. P. Goff. 2006. Parturition and hypocalcemia blunts calcium signals in immune cells of dairy cattle. J. Dairy Sci. 89:2588-2595.

Kvidera, S. K., E. A. Horst, M. Abuajamieh, E. J. Mayorga, M. V. Fernandez, and L. H. Baumgard. 2017. Glucose requirements of an activated immune system in lactating Holstein cows. J. Dairy Sci. 100:2360-2374.

Mann, S., F. A. L. Yepes, E. Behling-Kelly, and J. A. A. McArt. 2017. The effect of different treatments for early-lactation hyperketonemia on blood beta-hydroxybutyrate, plasma nonesterified fatty acids, glucose, insulin, and glucagon in dairy cattle. J. Dairy Sci. 100:6470-6482.

Martín-Tereso, J., and H. Martens. 2014. Calcium and magnesium physiology and nutrition in relation to the prevention of milk fever and tetany (dietary management of macrominerals in preventing disease). Vet. Clin. North Am. Food Anim. Pract. 30:643-670.

Martinez, N., C. A. Risco, F. S. Lima, R. S. Bisinotto, L. F. Greco, E. S. Ribeiro, F. Maunsell, K. Galvao, and J. E. Santos. 2012. Evaluation of peripartal calcium status, energetic profile, and neutrophil function in dairy cows at low or high risk of developing uterine disease. J. Dairy Sci. 95:7158-7172.

Martinez, N., L. D. Sinedino, R. S. Bisinotto, E. S. Ribeiro, G. C. Gomes, F. S. Lima, L. F. Greco, C. A. Risco, K. N. Galvão, D. Taylor-Rodriguez, J. P. Driver, W. W. Thatcher, and J. E. Santos. 2014. Effect of induced subclinical hypocalcemia on physiological responses and neutrophil function in dairy cows. J. Dairy Sci. 97:874-887.

Megahed, A. A., M. W. H. Hiew, S. A. El Badawy, and P. D. Constable. 2018. Plasma calcium concentrations are decreased at least 9 hours before parturition in multiparous Holstein-Friesian cattle in a herd fed an acidogenic diet during late gestation. J. Dairy Sci. 101:1365-1378.

Miltenburg, C. L. 2015. Management of peripartum dairy cows for metabolic health and immune function. Doctoral Thesis. Department of Population Medicine, University of Guelph, Ontario, Canada.

NRC. 2001. Nutrient Requirements of Dairy Cattle. 7th ed. Natl. Acad. Press, Washington, DC.

Neves, R. C., B. M. Leno, K. D. Bach, and J. A. A. McArt. 2018a. Epidemiology of subclinical hypocalcemia in early-lactation Holstein dairy cows: The temporal associations of plasma calcium concentration in the first 4 days in milk with disease and milk production. J. Dairy Sci. 101:9321-9331.

Neves, R. C., B. M. Leno, M. D. Curler, M. J. Thomas, T. R. Overton, and J. A. A. McArt. 2018b. Association of immediate postpartum plasma calcium concentration with early-lactation clinical diseases, culling, reproduction, and milk production in Holstein cows. J. Dairy Sci. 101:547-555.

Pinedo, P., J. Velez, G. Solano, N. Rodriguez, J. Naves, G. M. Schuenemann, and C. Risco. 2017. Effect of oral calcium administration on the cure and reproductive performance of Holstein cows diagnosed with puerperal metritis. J. Dairy Sci. 100:2917-2927.

Pohl, A., S. Bertulat, S. Borchardt, O. Burfeind, and W. Heuwieser. 2016. Randomized, controlled clinical trial on the efficacy of non- steroidal antiinflammatory drugs for the treatment of acute puerperal metritis in dairy cows. J. Dairy Sci. 99:8241-8249.

Pohl, A., O. Burfeind, and W. Heuwieser. 2015. The associations between postpartum serum haptoglobin concentration and metabolic status, calving difficulties, retained fetal membranes, and metritis. J. Dairy Sci. 98:4544-4551.

Reinhardt, T. A., J. D. Lippolis, B. J. McCluskey, J. P. Goff, and R. L. Horst. 2011. Prevalence of subclinical hypocalcemia in dairy herds. Vet. J. 188:122-124.

Roberts, T., N. Chapinal, S. J. Leblanc, D. F. Kelton, J. Dubuc, and T. F. Duffield. 2012. Metabolic parameters in transition cows as indicators for early-lactation culling risk. J. Dairy Sci. 95:30573063.

Rodríguez, E. M., A. Aris, and A. Bach. 2017. Associations between subclinical hypocalcemia and postparturient diseases in dairy cows. J. Dairy Sci. 100:7427-7434.

Sannmann, I., S. Arlt, and W. Heuwieser. 2012. A critical evaluation of diagnostic methods used to identify dairy cows with acute postpartum metritis in the current literature. J. Dairy Res. 79:436-444.

Seifi, H. A., S. J. LeBlanc, K. E. Leslie, and T. F. Duffield. 2011. Metabolic predictors of post-partum disease and culling risk in dairy cattle. Vet. J. 188:216-220.

Sheldon, I. M., G. S. Lewis, S. LeBlanc, and R. O. Gilbert. 2006 Defining postpartum uterine disease in cattle. Theriogenology 65:1516-1530.

Swets, J. A. 1988. Measuring the accuracy of diagnostic systems. Science 240:1285-1293.

Taylor, M. S., K. F. Knowlton, M. L. McGilliard, W. S. Swecker, J. D. Ferguson, Z. Wu, and M. D. Hanigan. 2009. Dietary calcium has little effect on mineral balance and bone mineral metabolism through twenty weeks of lactation in Holstein cows. J. Dairy Sci. 92:223-237.

Vasquez, A. K., D. V. Nydam, M. B. Capel, S. Eicker, and P. D. Virkler. 2017. Clinical outcome comparison of immediate blanket treatment versus a delayed pathogen-based treatment protocol for clinical mastitis in a New York dairy herd. J. Dairy Sci. 100:2992-3003.

Venjakob, P. L., S. Borchardt, and W. Heuwieser. 2017. Hypocalcemia-Cow-level prevalence and preventive strategies in German dairy herds. J. Dairy Sci. 100:9258-9266.

Venjakob, P. L., L. Pieper, W. Heuwieser, and S. Borchardt. 2018 Association of postpartum hypocalcemia with early-lactation milk yield, reproductive performance, and culling in dairy cows. J. Dairy Sci. 101:9396-9405.

Vieira-Neto, A., F. S. Lima, J. E. P. Santos, R. D. Mingoti, G. S. Vasconcellos, C. A. Risco, and K. N. Galvao. 2016. Vulvovaginal laceration as a risk factor for uterine disease in postpartum dairy cows. J. Dairy Sci. 99:4629-4637.

Waldron, M. R., B. J. Nonnecke, T. Nishida, R. L. Horst, and T R. Overton. 2003. Effect of lipopolysaccharide infusion on serum macromineral and vitamin D concentration in dairy cows. J. Dairy Sci. 86:3440-3446.

Wilhelm, A. L., M. G. Maquivar, S. Bas, T. A. Brick, W. P. Weiss, H. Bothe, J. S. Velez, and G. M. Schuenemann. 2017. Effect of serum calcium status at calving on survival, health, and performance of postpartum Holstein cows and calves under certified organic management. J. Dairy Sci. 100:3059-3067.

\section{ORCIDS}

W. Heuwieser ( https://orcid.org/0000-0003-1434-7083 